\title{
Long-term Treatment of Galactorrhoea and Hypogonadism with Bromocriptine
}

\author{
M. O. THORNER, \\ A. S. MCNEILLY, \\ C. HAGAN, \\ G. M. BESSER
}

British Medical fournal, 1974, 2, 419-422

\section{Summary}

Seventeen women and four men with galactorrhoea and associated hypogonadism have been treated with bromocriptine for 2 to 28 months. In 18 patients the gonadal status became normal as the galactorrhoea improved. The gonadally unresponsive patients had either pituitary tumours or premature menopause. Prolactin levels fell with treatment; withdrawal of the drug was associated with an increase in serum prolactin and a recurrence of the galactorrhoea and hypogonadism. Two patients tried to become pregnant on treatment and both succeeded. Raised prolactin levels appear to block the actions of the gonadotrophins at a gonadal level rather than prevent their synthesis or release; lowering prolactin secretion with bromocriptine allows resumption of normal gonadal function. Bromocriptine appears to be the treatment of choice for inappropriate lactation in association with hypogonadism on a long-term basis.

\section{Introduction}

The syndrome of inappropriate lactation has been shown usually to be associated with increased circulating prolactin levels (Frantz and Kleinberg, 1970; Forsyth et al., 1971; Hwang et al., 1971). Bromocriptine (2-brom- $\alpha$-ergocryptine, CB 154) specifically reduces prolactin secretion by an action at the pituitary level and has been shown to be effective in the suppression of lactation whether it be puerperal (Varga et al., 1972; Rolland and Shellekens, 1973) or pathological, and this is associated with a reduction in circulating prolactin levels (Lutterbeck et al., 1971; Besser et al., 1972 a ; Leutenegger et al., 1972; Del Pozo et al., 1973; Varga et al., 1973). Inappropriate lactation with high prolactin levels is usually associated with hypogonadism whether this be menstrual irregularity or amenorrhoea in women or impotence in men; early reports indicated that the gonadal function returns to normal as the hyperprolactinaemia and galactorrhoea abate during the early phases of bromocriptine therapy (Lutterbeck et al., 1971; Besser et al., 1972 a; Leutenegger et al., 1972; Varga et al., 1973).

We report our experience with long-term treatment of the galactorrhoea-hypogonadism syndrome with bromocriptine in 17 women and four men.

\section{Patients}

The 21 patients (tables I and II) were first seen at St. Bartholomew's Hospital between 1969 and 1973. Preliminary accounts of five of them have been given elsewhere (cases $1,4,10,18$, and 19; Besser et al., 1972 a). No patient had evidence of hepatic or

\footnotetext{
Medical Professorial Unit and Department of Chemical Pathology, St. Bartholomew's Hospital, London EC1A 7BE

M. O. THORNER, M.B., M.R.C.P., Lecturer

A. S. MCNEILLY, PH.D., Research Lecture

C. HAGEN, M.D., Research Fellow

G. M. BESSER, M.D., F.R.C.P., Senior Lecturer
}

renal disease and none gave a history of taking a drug likely to cause galactorrhoea, except for oestrogen and progestogen therapy in four cases. Six of the patients had previously been pregnant. Only one had evidence of acromegaly; there was no evidence of thyroid deficiency, and only in case 2 (with radiological evidence of a pituitary tumour) and case 18 was there evidence of adrenocortical deficiency.

Galactorrhoea.-In the women the galactorrhoea had been present for eight months to 10 years before presentation but in two it was found only on examination; in two others it had started in the post-partum period (see table III). Galactorrhoea in the men had been present for 3 to 15 months before presentation (see table IV).

Gonadal Status. - Thirteen women had had amenorrhoea for between six months and six years, preceded in two cases by irregular periods. Periods were irregular without amenorrhoea in four patients. Two patients had evidence of the polycystic ovary syndrome on gynaecography, and one was hirsute. Two amenorrhoeic women initially appeared to be suffering from premature menopause but this was confirmed by ovarian biopsy in only one, the ovary from the other patient containing normal but undeveloped ovarian follicles. The four men all had absent or reduced potency.

Oestrogen-Progestogen Therapy.-In four women galactorrhoea was preceded by treatment with an oestrogen-progestogen oral contraceptive preparation prescribed for irregular menstruation. In one patient the milk appeared during treatment and in the others it occurred afterwards.

Pituitary Fossa Radiography.-Seven patients (six women and one man) were shown to have abnormal fossae, and in two of the men the appearance was equivocal in view of a double contour to the floor of the fossa.

\section{Methods}

Details of the methods for measuring serum immunoreactive prolactin, luteinizing hormone $(\mathrm{LH})$, follicle-stimulating hormone (FSH), and growth hormone (GH) have been given elsewhere (McNeilly, 1973; Mortimer et al., 1973; McNeilly and Hagan, 1974). Plasma corticosteroids (Mattingly, 1962) and total urinary oestrogen (Brown et al., 1968, Searle) were measured fluorometrically. Plasma $17 \beta$-hydroxyandrogens (17-OHA) as a measure of testosterone and dihydrotestosterone concentrations were assayed by the technique of Anderson (1970).

In the assays used the normal ranges for serum LH (M.R.C. standard $68 / 40,77 \mathrm{IU} /$ ampoule) in male subjects was $0 \cdot 8-13.3$ $\mathrm{U} / \mathrm{l}$. and in female subjects in the follicular phase 1.4-9.8 U/1.; for FSH (M.R.C. standard 69/104, $10 \mathrm{IU} /$ ampoule) the normal range in male subjects was $0 \cdot 1-3.5 \mathrm{U} / 1$. and in female subjects in the follicular phase $0 \cdot 8-3 \cdot 2 \mathrm{U} / 1$. Plasma 17-OHA levels in male subjects normally range from 4.9 to $21.0 \mathrm{ng} / \mathrm{ml}$.

Clomiphene Stimulation Test.-A dose of $3 \mathrm{mg} / \mathrm{kg} /$ day up to a maximum of $200 \mathrm{mg} /$ day was given and the changes in serum gonadotrophin were followed for up to 10 days. In normal male subjects serum $L H$ has been shown usually to rise above the normal range in this time (Anderson et al., 1972). The normal range for menstruating women varies with the stage of the cycle (VandenBerg and Yen, 1973) and therefore comparisons of the results of the test in amenorrhoeic women with results in normal women is difficult. 
TABLE I-Basal Data on Women with Galactorrhoea

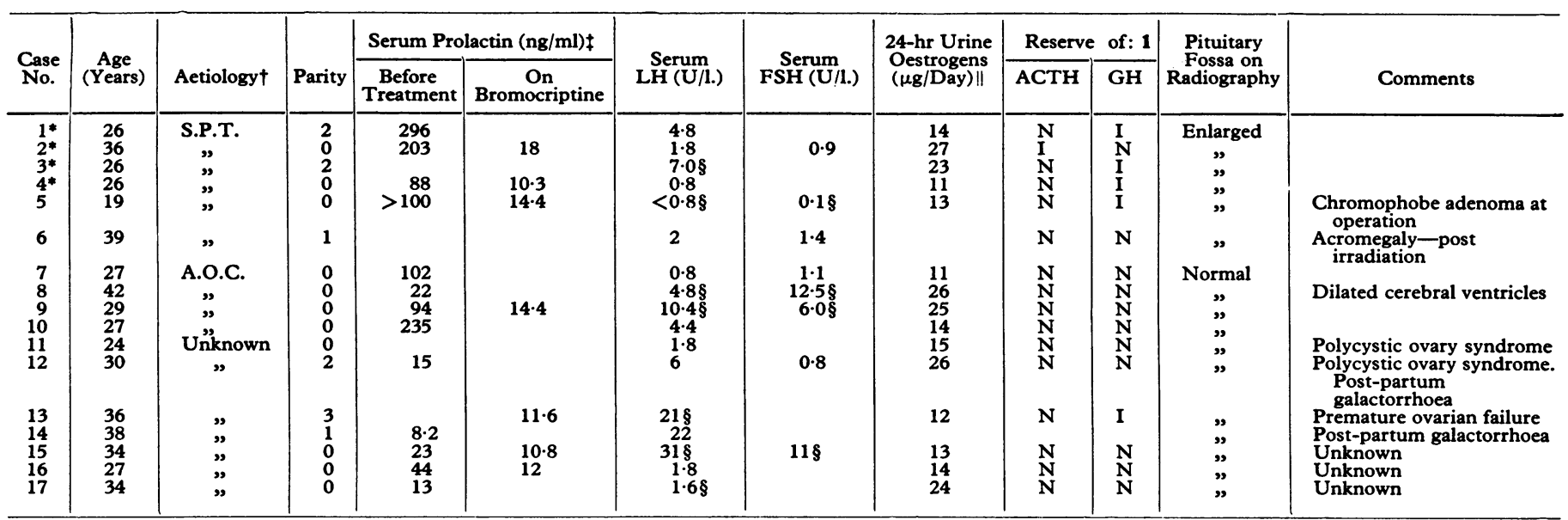

*Presumed pituitary tumour from radiographical evidence.

+ S.P.T. = Suspected pituitary tumour. A.O.C. = After oral contraceptive.

$\ddagger$ Normal range $6-25 \mathrm{ng} / \mathrm{ml}$.

SExcessive response to $\mathrm{LH} / \mathrm{FSH}-\mathrm{RH}$.

1Bormal range (follicular phase) $7-30 \mu \mathrm{g} / \mathrm{day}$.
Based on responses to insulin tolerance test. $\mathrm{N}=$ Normal. $\mathrm{I}=$ Impaired. (Hall et al., 1972.)

TABLE II-Basal Data on Men with Galactorrhoea

\begin{tabular}{|c|c|c|c|c|c|c|c|c|c|c|c|}
\hline \multirow{2}{*}{$\begin{array}{l}\text { Case } \\
\text { No. }\end{array}$} & \multirow{2}{*}{$\begin{array}{c}\text { Age } \\
\text { (Years) }\end{array}$} & \multirow{2}{*}{ Aetiology $\dagger$} & \multicolumn{2}{|c|}{ Serum Prolactin $(\mathrm{ng} / \mathrm{ml}) \ddagger$} & \multirow{2}{*}{$\begin{array}{l}\text { Serum } \\
\mathbf{L H} \\
(\mathbf{U} / \mathbf{l} .)\end{array}$} & \multirow{2}{*}{$\begin{array}{c}\text { FSH } \\
\text { (U/1.) }\end{array}$} & \multirow{2}{*}{$\begin{array}{c}\text { Plasma } \\
17-O H A \\
(\mathrm{ng} / \mathrm{ml}) \S\end{array}$} & \multicolumn{2}{|c|}{ Reserve of:1 } & \multirow{2}{*}{$\begin{array}{c}\text { Pituitary } \\
\text { Fossa on } \\
\text { Radiography }\end{array}$} & \multirow{2}{*}{ Comments } \\
\hline & & & $\begin{array}{c}\text { Before } \\
\text { Treatment }\end{array}$ & $\stackrel{\text { On }}{\text { Bromocriptine }}$ & & & & АСTH & GH & & \\
\hline $\begin{array}{l}18 \\
19^{*} \\
20^{*} \\
21\end{array}$ & $\begin{array}{l}36 \\
26 \\
20 \\
28\end{array}$ & $\begin{array}{l}\text { S.P.T. } \\
\text { "” } \\
\text { Unknown }\end{array}$ & $\begin{array}{r}1,572 \\
899 \\
73 \\
30\end{array}$ & $\begin{array}{r}7 \cdot 1 \\
<22 \\
13 \cdot 8 \\
13 \cdot 9\end{array}$ & $\begin{array}{l}3 \cdot 2 \\
4 \cdot 8 \\
5 \cdot 6 \\
2 \cdot 4\end{array}$ & $\begin{array}{l}1 \cdot 7 \\
0.75\end{array}$ & $\begin{array}{r}5 \cdot 3 \\
8 \cdot 5 \\
10 \cdot 7 \\
4 \cdot 8\end{array}$ & $\begin{array}{l}\mathbf{I} \\
\mathbf{N} \\
\mathbf{N} \\
\mathbf{N}\end{array}$ & $\begin{array}{l}\mathbf{I} \\
\mathbf{N}\end{array}$ & $\begin{array}{l}\text { Enlarged } \\
\text { Equivocal } \\
\text { Equivocal } \\
\text { Normal }\end{array}$ & Chromophobe adenoma at operation \\
\hline
\end{tabular}

*Presumed pituitary tumour from radiographical evidence.

$\dagger$ S.P.T. = Suspected pituitary tumour.

†Normal range $6-25 \mathrm{ng} / \mathrm{ml}$.

1Based on responses to insulin tolerance test. $\mathrm{N}=$ Normal. $\mathrm{I}=$ Impaired. (Hall et al., 1972.)

Gonadotrophin-releasing hormone tests were performed using $100 \mu \mathrm{g}$ gonadotrophin-releasing hormone (LH/FSH-RH, Hoechst) intravenously as a bolus with measurement of serum LH and FSH at 0, 20, and 60 minutes (Besser et al., 1972 b; Mortimer et al., 1973).

Bromocriptine Therapy. - Treatment was usually started with a dose of $2.5 \mathrm{mg}$ twice daily with food and increased after two months if full clinical improvement, as indicated by cessation of galactorrhoea and return of normal gonadal function, had not been attained. Treatment was arbitrarily stopped after 2 to 28 months in nine patients.

\section{Results}

The clinical and biochemical responses to treatment are shown in tables III and IV.

Galactorrhoea was improved in all the patients. The improvement usually became noticeable within one week and ceased completely in 12 cases between one week and three months after starting therapy (tables III and IV). In five cases a trace of breast milk could still be expressed but the breasts did not discharge spontaneously and did not inconvenience the patient. In one patient with premature ovarian failure (case 13) the galactorrhoea was initially reduced but was still troublesome and could not be further influenced with oestrogen. In six of the patients in whom treatment was withdrawn after one year or more the galactorrhoea recurred within three days to two weeks but responded again on resumption of bromocriptine. Two other patients had treatment stopped when they became pregnant.

Gonadal Status.-In 11 of the 13 patients with amenorrhoea (table III) menstruation was restored from 3 to 24 weeks after starting therapy with bromocriptine. The three patients whose gonadal function did not change had the following associated con- ditions: hypophysectomy and pituitary irradiation, acromegaly, and premature ovarian failure. Three patients previously had irregular or heavy periods but not amenorrhoea with the galactorrhoea uncomplicated by pituitary disease, and these were restored to normal. Two patients attempted to become pregnant and both succeeded within two months; one was delivered of a normal child and the other was still pregnant. All four male patients (table IV) regained normal potency within six months. Therapy was withdrawn from nine responsive patients with the following results (tables III and IV): amenorrhoea recurred in four patients, periods became irregular in one, one was pregnant, and one man became impotent again.

Prolactin levels were measured basally in 17 patients and were raised in 12 (tables I and II). In response to bromocriptine serum prolactin was reduced to normal in each of the 11 patients in whom it was measured during treatment. In three patients prolactin levels were measured again after stopping treatment and they were again raised (tables III and IV).

Gonadotrophins.-Serum LH and FSH levels were detectable and normal in all patients before treatment except for cases 9, 13 , and 15, in which they were raised (table I). When treated with clomiphene before bromocriptine therapy (table V) the eight women with normal basal gonadotrophin levels showed a definite rise in gonadotrophins but in none did the level exceed the normal range for the follicular phase of the cycle, and this response was probably impaired. The responses to clomiphene were impaired in all three men tested. Seven out of 11 women but neither male tested with LH/FSH-RH had excessive gonadotrophin responses. Despite these abnormal gonadotrophin findings 18 of the 21 patients with disordered gonadal function reverted to apparently normal gonadal status with abolition of the galactorrhoea on bromocriptine therapy.

Dose of Bromocriptine.-Maintenance doses of 5 to $32 \mathrm{mg} /$ day were used but the usual dose was $7.5 \mathrm{mg} /$ day. The duration of the treatment was 2 to 28 months. 
Side Effects.-The only side effects were dyspepsia and nausea in five patients, and these occurrred about two hous after drug administration. The symptoms were particularly severe when treatment was initiated and when taken on an empty stomach; they could be avoided in most cases by taking the capsules in the middle of a meal. When symptoms continued the dose was reduced to $1 \mathrm{mg}$ twice daily for a time, after which it could be gradually increased without recurrence of symptoms. In no case was it necessary to withhold treatment because of side effects. Though bromocriptine is an ergot alkaloid there were no symptoms or signs of ergotism or digital vasospasm. Five patients lost from 3.5 to $18 \mathrm{~kg}$ in weight over 3 to 18 months in spite of no apparent change in appetite or food intake. They had all gained this weight during the time that they had been galactorrhoeic.

\section{Discussion}

Altogether 20 of the 21 patients with galactorrhoea responded to bromocriptine with reduction or cessation of galactorrhoea, and gonadal function was restored to normal in 14 of the 17 women and in all four men. When serum prolactin levels were measured during treatment they had in all cases been reduced to normal. When treatment was withdrawn galactorrhoea returned in all but one case and each patient again became hypogonadal but the symptoms abated again when bromocriptine therapy was resumed. Side effects were not a serious problem and were present in only a quarter of the patients, and only as therapy started. The early side effects of dyspepsia and nausea were avoided either by taking the drug with food or by reducing the dose for a short while; it was never necessary to withhold treatment because of side effects. These results confirm our preliminary findings (Besser et al., 1972 a) and indicate that this compound may be used for continuous therapy without any escape of prolactin secretion or recurrence of galactorrhoea while on bromocriptine; prolonged treatment, up to 28 months in two cases, was devoid of adverse effects. We have no evidence, however, that the underlying pathological process is altered by bromocriptine therapy.

TABLE III-Women. Duration of Galactorrhoea and Amenorrhoea and Eff scts of Treatment

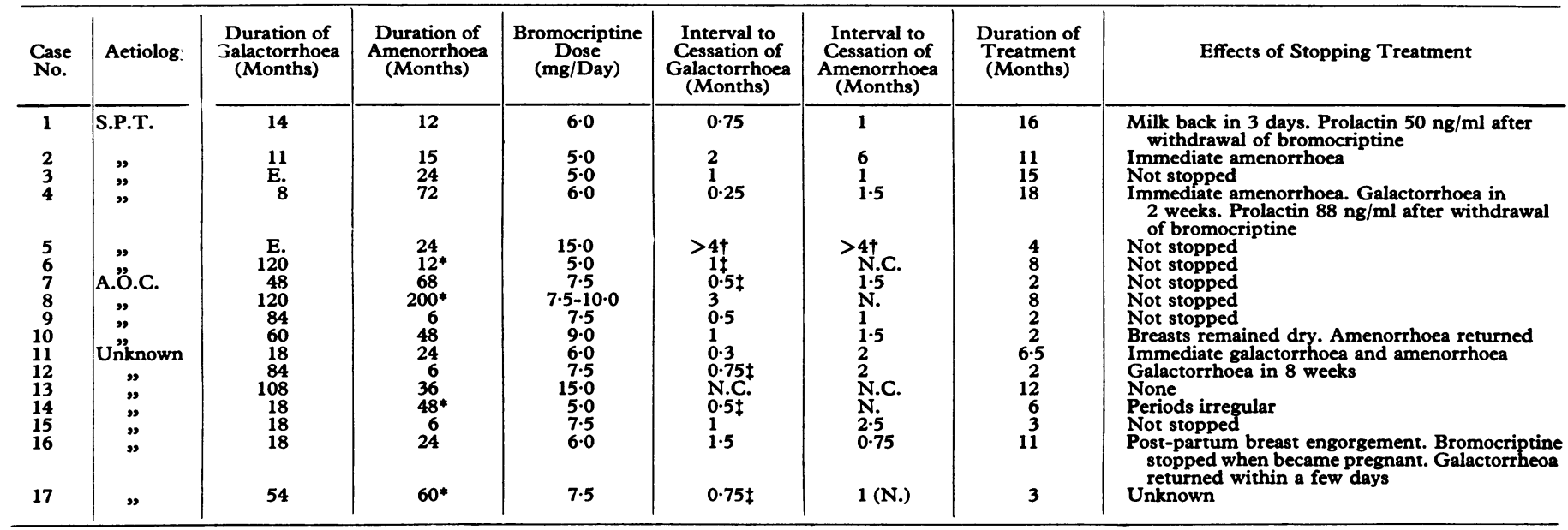

*Dysfunctional bleeding (irregular, often heavy menstruation).

tHad not stopped.

$\mathrm{E}=$ Found only on examination. $\mathrm{N} . \mathrm{C} .=$ No change. $\mathrm{N}=$ Periods normalized.

TABLE IV-Men. Duration of Galactorrhoea and Impotence and Effects of Treatment

\begin{tabular}{|c|c|c|c|c|c|c|c|c|}
\hline $\begin{array}{l}\text { Case } \\
\text { No. }\end{array}$ & Aetiology & $\begin{array}{l}\text { Duration of } \\
\text { Galactorrhoea } \\
\text { (Months) }\end{array}$ & $\begin{array}{l}\text { Duration of } \\
\text { Impotence } \\
\text { (Months) }\end{array}$ & $\begin{array}{c}\text { Bromocriptine } \\
\text { Dose } \\
\text { (mg/Day) }\end{array}$ & $\begin{array}{l}\text { Interval to } \\
\text { Cessation of } \\
\text { Galactorrhoea } \\
\text { (Months) }\end{array}$ & $\begin{array}{l}\text { Interval to } \\
\text { Cessation of } \\
\text { Impotence } \\
\text { (Months) }\end{array}$ & $\begin{array}{l}\text { Duration of } \\
\text { Treatment } \\
\text { (Months) }\end{array}$ & Effects of Stopping Treatment \\
\hline 18 & $\begin{array}{c}\text { S.P.T. } \\
y\end{array}$ & $\begin{array}{r}3 \\
18\end{array}$ & $\begin{array}{l}24 \\
18\end{array}$ & $\begin{array}{l}9 \cdot 0 \\
6 \cdot 0\end{array}$ & $\begin{array}{l}3 \\
2\end{array}$ & $\begin{array}{l}6 \\
1\end{array}$ & $\begin{array}{l}28 \\
28\end{array}$ & Not stopped \\
\hline 20 & Unknown & $\begin{array}{r}4 \\
15\end{array}$ & $\begin{array}{c}36 \\
?\end{array}$ & $\begin{array}{r}32 \cdot 0 \\
5 \cdot 0\end{array}$ & $\begin{array}{l}3 * \\
0.5+\end{array}$ & ? & $\begin{array}{l}4 \\
8 \cdot 5\end{array}$ & $\begin{array}{l}\text { Not stopped } \\
\text { Not stopped }\end{array}$ \\
\hline
\end{tabular}

*Had not stopped.
†Trace of milk persisted.

TABLE v-Gonadotrophin Responses to Clomiphene on Days 0, 5, 7, and 10

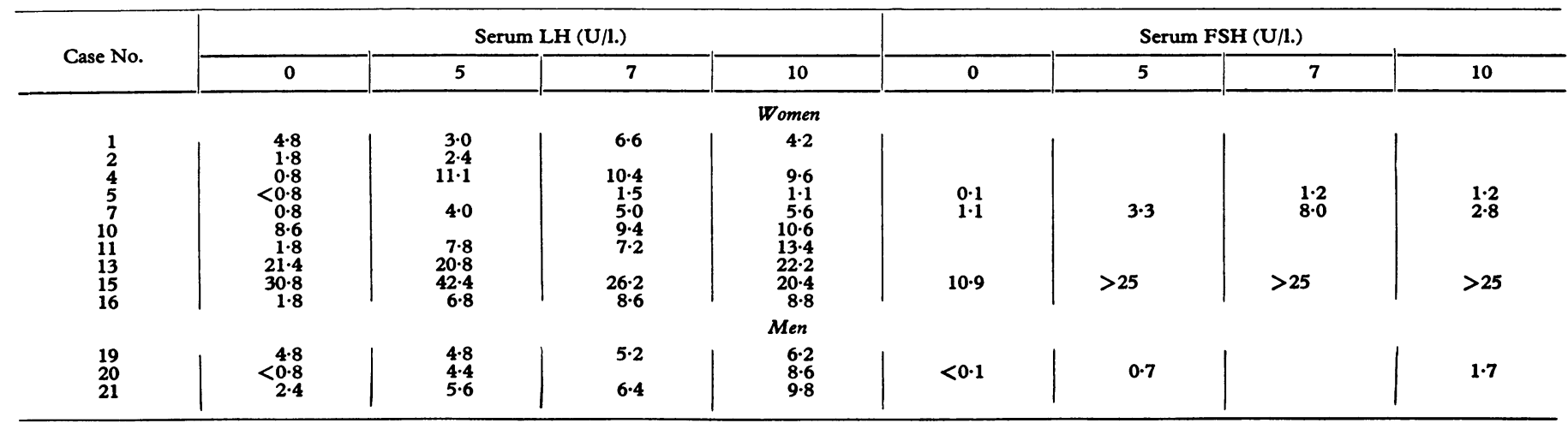


Bromocriptine is a potent suppressor of prolactin secretion, and this has been confirmed both clinically and by measuring the circulating prolactin levels. Levodopa also suppresses prolactin secretion but has the disadvantage that its duration of action is short (Malarkey et al., 1971), the incidence of side effects is high with doses necessary for adequate suppression, and it does not consistently improve galactorrhoea (Copinschi et al., 1973). Recent work indicates that bromocriptine is a dopaminergic agonist (Corrodi et al., 1973), and it is possible that its suppression of prolactin is through this mechanism but with a more prolonged length of action than levodopa. The therapeutic actions as well as the side effects would be compatible with this as they are very similar to those of levodopa.

Before treatment all the patients had either menstrual irregularities or amenorrhoea or impotence. Nevertheless, basal gonadotrophin levels were normal in all patients but two, both of whom had high rather than low levels. Excessive responses to $\mathrm{LH} / \mathrm{FSH}-\mathrm{RH}$ were seen in seven out of 13 patients tested but there was no correlation between gonadotrophin levels and the levels of circulating immunoreactive prolactin, and this excessive response to $\mathrm{LH} / \mathrm{FSH}-\mathrm{RH}$ confirms our previous report (Mortimer et al., 1973). A normal response may also occur but we have not seen an impaired response in this context, in contrast to the experience of others (Zarate et al., 1973).

In the galactorrhoea syndromes the gonadal function is usually impaired irrespective of whether immunoreactive prolactin levels are raised. When these patients are treated with bromocriptine and prolactin levels fall the gonadal function usually returns to normal. The only patients in whom this did not occur in the present series were two with pituitary tumour and one with a premature menopause. In five patients the gonadal function became normal with cessation of galactorrhoea even though radiographical evidence of a pituitary tumour was present. The hypogonadism which exists in association with the pretreatment galactorrhoea does not appear to be due to inadequate gonadotrophin synthesis or reserve as the responses to $\mathrm{LH} / \mathrm{FSH}-\mathrm{RH}$ are not impaired; however, the responses to clomiphene, which normally acts through the hypothalamus, are impaired. This situation is analogous to that in post-partum women in whom gonadotrophin secretion occurs early during lactation but does not cycle normally for some time and oestrogen secretion is low (Reyes et al., 1972). During puerperal lactation the ovaries appear to be refractory to exogenous gonadotrophin during the time that prolactin secretion is increased (Zarate et al., 1972). It appears, therefore, that the raised prolactin levels in some way have antigonadotrophic actions at the gonadal level.

It seems likely that the hypogonadism in patients with pathological lactation is secondary to an inappropriately raised prolactin level, since the hypogonadism as well as the galactorrhoea respond to bromocriptine, which specifically blocks prolactin secretion. The reduction in prolactin appears to allow the circulating gonadotrophin levels to act on the gonad to stimulate steroidogenesis. The sex steroids then may feed back on the hypothalamus and pituitary to allow normal release of gonadotrophins, leading to a return of normal gonadal function, ovulation, and spermatogenesis.

One of the patients with persistently raised gonadotrophin levels, galactorrhoea, and amenorrhoea was of particular interest.
It was initially tempting to ascribe a diagnosis of a premature menopause to her; however, ovarian biopsy showed the presence of follicles and treatment with bromocriptine resulted in cessation of the galactorrhoea with regular menstruation. Similarly two patients had galactorrhoea with the polycystic ovary syndrome and both responded well. This association was described by Forbes et al. (1954), and a number of their patients had hirsuties and seborrhoea as well as galactorrhoea and amenorrhoea or irregular periods. They also noted urinary 17-oxosteroid excretion at the upper limit of normal, or above, and we recorded this in six of our women and one of the men. It seems possible that prolactin may alter adrenocortical androgen production. The amenorrhoea associated with oral contraceptive medication also responds well to bromocriptine if galactorrhoea is present as well. A trial of this drug in post-oral contraceptive amenorrhoea without galactorrhoea is currently taking place.

Bromocriptine is an effective, safe, and satisfactory long-term treatment for galactorrhoea and it reverses the associated hypogonadism in both men and women. It appears to be the treatment of choice for this condition, since it is effective and devoid of adverse effects.

We are grateful to Dr. R. Evans, of Sandoz Products Ltd., for the provision of bromocriptine, to the Peel Medical Trust, the Joint Research Board of St. Bartholomew's Hospital, and the Wellcome Trust for financial support, and the physicians who referred the patients.

\section{References}

Anderson, D. C. (1970). Clinica Chimica Acta, 29, 513.

Anderson, D. C., et al. (1972). Clinical Endocrinology, 1, 127.

Besser, G. M., et al. (1972 a). British Medical fournal, 3, 669.

Besser, G. M., et al. (1972 b). British Medical fournal, 3, 267.

Brown, J. B., et al. (1968). Fournal of Endocrinology, 42, 5.

Copinschi, G., et al. (1973). In Hormones and Antagonists, ed. P. Hubimont, S. M. Hendeles, and P. Premont, p. 128. Basle, Karger.

Corrodi, H., et al. (1973). Fournal of Pharmacy and Pharmacology, 25, 409.

Del Pozo, E., Friesen, H. G., and Burmeister, P. (1973). Schweizerische medizinische Wochenschrift, 103, 847.

Forbes, A. P., et al. (1954). Fournal of Clinical Endocrinology and Metabolism, 14,265 .

Forsyth, I. A. et al. (1971). British Medical fournal, 3, 225.

Frantz, A. G., and Kleinberg, D. L. (1970). Science, 170, 745

Frant, R., et al. (1972). Lancet, 1, 759 .

Hall, R., et al. (1972). Lancet, 1, 759. National Academy of Sciences, 68, 1902 .

Leutenegger, M., et al. (1972). Schweizerische Rundschau für Medizin, 23, 762 .

Lutterbeck, P. M., et al. (1971). British Medical fournal, 3, 228.

McNeilly, A. S. (1973). Proceedings of the Royal Society of Medicine, 66, 863.

McNeilly, A. S., and Hagan, C. (1974). Clinical Endocrinology. In press.

Malarkey, W. B., Jacobs, L. S., and Daughaday, W. H. (1971). New England fournal of Medicine, 285, 1160 .

Mattingly, D. (1962). Fournal of Clinical Pathology, 15, 374.

Mortimer, C. H., et al. (1973). British Medical fournal, 3, 73.

Reyes, F. I., Winter, J. S. D., and Faiman, C. (1972). American fournal of Obstetrics and Gynecology, 114, 589.

Rolland, R., and Shellekens, L. (1973). Fournal of Obstetrics and Gynaecology of the British Commonwealth, 80, 945.

VandenBerg, G., and Yen, S. S. C. (1973). Fournal of Clinical Endocrinology and Metabolism, 37, 356 .

Varga, L., et al. (1972). British Medical fournal, 2, 743.

Varga, L., et al. (1972). British Medical fournal, 2, 743.
Varga, L., Wenner, R., and Del Pozo, E. (1973). American fournal of Obstetrics and Gynecology, 117, 75.

Zarate, A., et al. (1972). American Ұournal of Obstetrics and Gynecology, 112, 1130 .

Zarate, A., et al. (1973). fournal of Clinical Endocrinology and Metabolism, 37, 855. 